\title{
Essential elements, oil and protein contents of sunflower hybrids grown in Brazil
}

\author{
Elementos essenciais, teores de óleo e proteína de híbridos de girassol \\ cultivados no Brasil
}

\section{Rívia Darla Alvares Amaral ${ }^{1 *}$, Roseli Aparecida Ferrari', Luana Cristina Rabonato', Marcelo Antônio Morgano1, Flávio Carlos Dalchiavon ${ }^{2}$, Rafaela Souza Oliveira ${ }^{1}$}

\author{
1 Instituto de Tecnologia de Alimentos, Centro de Ciência e Qualidade dos Alimentos, Campinas/SP-Brasil \\ 2 Instituto Federal de Educação, Ciência e Tecnologia de Mato Grosso, Campo Novo do Parecis/MT - Brasil
}

\section{*Corresponding Author}

Rívia Darla Alvares Amaral, Instituto de Tecnologia de Alimentos, Centro de Ciência e Qualidade dos Alimentos, Av. Brasil, 2880, CEP: 13070-178, Campinas/SP - Brasil, e-mail: riviamaral@yahoo.com.br

Cite as: Essential elements, oil and protein contents of sunflower hybrids grown in Brazil. Braz. J. Food Technol., v. 21, e2017065, 2018.

Received: May 10, 2017; Accepted: Apr. 06, 2018

\section{Abstract}

In this research the mineral elements and the oil and protein contents of thirteen sunflower hybrids grown in Brazil, were studied. In addition, the possibility of jointly obtaining products with high productivity and high oil and protein contents was evaluated. The research showed high achene productivity, exceeding the national average, mainly by the hybrids BRS G44, SYN 045 and M 734. It should be taken into account that some hybrids, such as NTC 90, despite their high productivity, are not suitable for production when the purpose is to obtain oil and protein meal. The hybrid BRS G46 presented high oil and protein contents. On the other hand, SYN 065 was the least productive $\left(808.10 \mathrm{~kg} \mathrm{ha}^{-1}\right)$ and, despite the fact that this hybrid showed an above average oil content, it showed the lowest protein content of the grains analysed. In general, the samples analysed had higher concentrations of $\mathrm{K}, \mathrm{Mg}, \mathrm{S}, \mathrm{Fe}, \mathrm{Zn}, \mathrm{Mn}, \mathrm{Cr}$, Ni and $\mathrm{Cu}$, whereas the mineral contents of $\mathrm{Mo}, \mathrm{Co}$ and Se were present at lower levels. The hybrid BRS G45 indicated the presence of larger amounts of elements at higher concentrations, such as: Mg, S, Cr, Fe, Ni, Cu and Zn, followed by BRS G44, which showed higher contents of Mg, Cr, $\mathrm{Mn}, \mathrm{Fe}$ and $\mathrm{Ni}$. The characterization of the Brazilian hybrids in this study allowed for their differentiation for specific purposes and the possibility of oil production combinations, producing oils with characteristics that make them apt for alternative uses of their by-products (such as the hybrid BRS G46), this being a great opportunity to increase the farm income.

Keywords: Inorganic elements; Helianthus annuus; ICP-MS; Productivity; Lipid content.

\section{Resumo}

No presente trabalho, foram determinados os elementos minerais, os teores de óleo e proteína de 13 híbridos de girassol. Além disso, foi avaliada a possibilidade de se obterem, conjuntamente, produtos com alta produtividade e altos teores de óleo e proteína. A pesquisa mostrou alta produtividade de aquênios, excedendo a média nacional, principalmente para os híbridos BRS G44, SYN 045 e M 734. Deve-se levar em conta que alguns híbridos, como o NTC 90, apesar de apresentar alta produtividade, não são adequados para a produção quando o objetivo é a obtenção de óleo e farinha proteica. O híbrido BRS G46 apresentou alto teor de óleo e proteína. Por outro lado, SYN 065 foi o menos produtivo $\left(808,10 \mathrm{~kg} \mathrm{ha}^{-1}\right)$ e, apesar de este híbrido mostrar teor de óleo acima da média, apresentou o menor teor de proteína entre os grãos analisados. De uma forma geral, as amostras analisadas apresentaram concentrações mais elevadas de K, Mg, S, Fe, Zn, Mn, Cr, Ni e Cu, enquanto que o conteúdo mineral de Mo, Co e Se estava presente em níveis mais baixos. O híbrido BRS G45 indicou a presença de grandes quantidades de elementos a altas concentrações, como Mg, S, Cr, Fe, Ni, Cu e Zn, seguido pelo BRS G44, que mostrou maiores concentrações de $\mathrm{Mg}, \mathrm{Cr}$, Mn, Fe e Ni. A caracterização dos híbridos brasileiros, neste estudo, permitiu a sua diferenciação para uma finalidade específica e a possibilidade da combinação de produção de óleo, com características que os tornam aptos para usos alternativos de seus subprodutos (como o híbrido BRS G46), constituindo, assim, uma boa oportunidade para aumentar a renda agrícola.

Palavras-chave: Elementos inorgânicos; Helianthus annuus; ICP-MS; Produtividade; Teor de óleo. 


\section{Introduction}

Sunflower (Helianthus annuus L.) is a very versatile crop cultivated in several regions in the world. The cultivars are selected to supply specific requirements, such as oil production, human or animal nutrition and biodiesel production. Regarding oil production, sunflower is the fourth oilseed in the world, coming after palm, soybean and rapeseed. In Brazil, the Midwest region responds for the greatest production, corresponding to $79.8 \%$ of the planted area (CONAB, 2015; FORCE et al., 2015). The production of new hybrids started in the mid-seventies in the United States, providing higher yields and oil enhancement as well as disease resistance (GUPTA, 2014).

In this context, the tagging of the mineral composition of sunflower hybrids stimulates the growing interest in evaluating the macro and microelements in a range of foods, supplying information necessary for a healthy diet based on the nutritional properties (KIRBASLAR et al., 2012). Elemental mapping could help understand which elements have similar distribution behaviours in the plant and alter the biochemical functions. Macro elements such as $\mathrm{Ca}, \mathrm{K}, \mathrm{Mg}$ and $\mathrm{S}$ are required and large amounts are taken up by the plants. On the other hand, micro elements (Co, Cu, Mn, Ni, and $\mathrm{Zn}$ ) are also essential, but can become toxic if they exceed certain levels in the plant (KÖTSCHAU et al., 2014).

The possible interferences in mineral plant nutrition suggest the use of certain statistical tools to evaluate information about the composition of inorganic elements with respect to several variables, such as different genotypes of the same culture. Determined systems, such as the hierarchical cluster analysis (HCA), use algorithms to elaborate charts, which reproduce a set of analytical data providing the largest possible amount of information (CORREIA; FERREIRA, 2007).

Regarding crop productivity, the yields in achenes and head components are specific to the sunflower hybrid, although they may be influenced by different growing factors (environmental and technological factors) (ION et al., 2015). In sunflower breeding programs the main selection criterion is the oil yield, represented by the product of grain and grain-oil concentration, which also best represents the real return to farmers. The fact that these programs do not only release hybrids that outperform the current market cultivars with respect to oil yield, but that each variety has its specific purpose, is another aspect to be considered (DE LA VEGA et al., 2007). The low-oil varieties (38\% to $47 \%$ oil) have frequently been replaced by high-oil hybrids (47\% to $53 \%$ oil) (ALBERIO et al., 2016), and several authors have reported the effects of agronomical practices on oil quality. Roche et al. (2004) affirmed that the oil content is positively influenced by colder temperatures and by the water supply during the lipid accumulation phase and Izquierdo et al. (2002) stated that hybrid selection is the most important agronomical practice to obtain a defined oil quality. Besides these factors, the effects of the sowing date, location and temperature should also be considered when predicting the oil quality, due to their influence on the percentage of oleic acid.

Thus many questions should be investigated using a large database that represents the target population of environments for the crop and in which every commercial cultivar was tested, allowing for the selection of the best hybrid to optimize the productivity in the environment for which it was developed (DE LA VEGA et al., 2007). Key challenges include the development of new plants with high productivity and high oil and protein contents but at present, few hybrids manage to combine these characteristics. Thus the aim of this research was to determine the mineral composition (essential and non-essential elements) of sunflower hybrids grown in Brazil, as well as their productivity and oil and protein contents.

\section{Materials and methods}

\subsection{Experimental area}

\subsubsection{Experimental setup and sampling}

The study was carried out from February to June of 2015 in Typic Tropudox soil (DALCHIAVON et al., 2015) at an experimental production sector of the Federal Institute of Education, Science and Technology of Mato Grosso IFMT, located in the Midwest region of Brazil (1340'37" S and $\left.57^{\circ} 47^{\prime} 30^{\prime \prime} \mathrm{W}\right)$. The initial fertility characterization for the 0 to $0.20 \mathrm{~m}$ layer showed the following values: $\mathrm{pH}$ $\left(\mathrm{CaCl}_{2}\right)=5.0 ; \mathrm{OM}=35.8 \mathrm{~g} \mathrm{dm}^{-3} ; \mathrm{P}($ resin $)=6.1 \mathrm{mg} \mathrm{dm}^{-3}$; $\mathrm{K}, \mathrm{Ca}, \mathrm{Mg}$ and $\mathrm{H}+\mathrm{Al}=2.4 ; 25 ; 10$ and $46 \mathrm{mmol}_{\mathrm{c}} \mathrm{dm}^{-3}$, respectively; with $\mathrm{V}=45.0 \%$.

Thirteen sunflower (Helianthus annuus L.) oilseed hybrids (BRS G43, BRS G44, BRS G45, BRS G46, HLA 2013, HLA 2014, HLA 2015, HLA 2016, HLA 2017, SYN 045, SYN 065, NTC 90 and M734) were grown in a randomized complete block design with four replications. The hybrids were sown manually on June 1 st in four rows, each $7.0 \mathrm{~m}$ long, spaced $45 \mathrm{~cm}$ apart and adopting $0.05 \mathrm{~m}$ of approximate depth. The total area was $655.20 \mathrm{~m}^{2}$. Two unsown rows on each side of each plot were used as borders and not considered as useful plot area. Prior to sowing, $100 \mathrm{~kg} \mathrm{ha}^{-1}, 200 \mathrm{~kg} \mathrm{ha}^{-1}$ and $4 \mathrm{~kg} \mathrm{ha}^{-1}$ of MAP, NPK 16-16-16 and ESPHERIC ${ }^{\circledR}$ (2\% N, 4,82\% S, 10\% B, $5 \% \mathrm{Zn})$, respectively, were incorporated into the soil in a direct seeding system, due to recommendations made after interpreting the soil analysis (SOUSA; LOBATO, 2004). Thinning was carried out 25 days after sowing

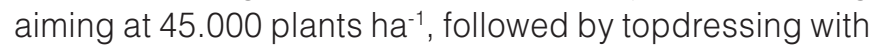
$56.35 \mathrm{~kg} \mathrm{ha}^{-1}, 11 \%$ and $14 \mathrm{~kg} \mathrm{ha}^{-1}$ of NPK 33-00-00, S and ESPHERIC ${ }^{@}(2 \%$ N, 4,82\% S, 10\% B, 5\% Zn), respectively, 30 days after sowing. Weed control was carried out with the help of pesticides, according to the needs of the crop. 
Essential elements, oil and protein contents of sunflower hybrids grown in Brazil

Amaral, R. D. A. et al.

The following agronomical traits were evaluated: days for initial flowering (DIF), when 50\% of the plants in the plot showed yellow petals, $\mathrm{R}_{4}$; harvest index $(\mathrm{HI})$, determined by the ratio between the achene mass in ten heads and the mass of these heads; the mass of a thousand achenes (MTA), obtained by counting and weighing ten samples and their productivity in achenes (PRO; $\mathrm{kg} \mathrm{ha}^{-1}$ ), based on two main 5-metre lines, which were adjusted to a moisture content of $11 \%$ (wet basis) after obtaining the reading for the moisture content of the achenes, and calculating according to Equation 1 (DALCHIAVON et al., 2011):

$$
\mathrm{PRO}=\mathrm{P} \cdot[(100-\mathrm{Uob}) /(100-\mathrm{Ud})]
$$

where $P$ represents the uncorrected field mass of achenes ( $\left.\mathrm{kg} \mathrm{ha}^{-1}\right)$; Uob the moisture content of each batch (\%) and Ud the desired standard moisture content (11\%).

The heads were harvested manually from the two central $5 \mathrm{~m}$ lines in $\mathrm{R}_{9}$, using pruning shears. They were then dried naturally, tracked, cleaned manually and weighed. The results were submitted to an analysis of variance followed by the Scott-Knott average test, both at 5\% probability and using the SISVAR statistical program (FERREIRA, 2011).

Table 1 shows the weather data obtained from a weather station located inside the Institute where the seeds were grown, from February to June of 2015.

The mean temperature varied from $22.32^{\circ} \mathrm{C}$ to $24.02^{\circ} \mathrm{C}$ in the planting area during the sunflower growing period, with maximum and minimum temperatures reaching $31.03^{\circ} \mathrm{C}$ and $15.89^{\circ} \mathrm{C}$, respectively. This temperature range is in good agreement with the scientific literature available from other studies carried out with sunflower (ROCHE et al., 2006).

The amount of rainfall for the same period was $816 \mathrm{~mm}$, which meets the demands of the culture for fluid perfectly, since this requires an accumulated precipitation of 500 to $700 \mathrm{~mm}$ evenly distributed throughout its cycle (CASTRO; FARIAS, 2005).

\subsection{Grain characterization}

The samples were prepared by homogenization in a batch mill with a tungsten helix (M20, IKA Labortechnik, Staufen, Germany) and then sieved through a 60 mesh sieve. All measurements were carried out in triplicate.

\subsubsection{Moisture content}

Samples of $5.0 \pm 0.5 \mathrm{~g}$ were dried at $130{ }^{\circ} \mathrm{C}$ for $3 \mathrm{~h}$ (FIRESTONE, 2014). The final moisture content (\%) was calculated relative to the initial mass of wet sample.

\subsubsection{Ash content}

The ash content was determined in an oven previously set at $550 \pm 10^{\circ} \mathrm{C}$ and expressed relative to the initial mass of grains (ZENEBON; PASCUET, 2005).

\subsubsection{Total lipids content}

Samples of $4.0 \pm 0.5 \mathrm{~g}$ were subjected to extraction with petroleum ether $\left(30^{\circ} \mathrm{C}\right.$ to $\left.60^{\circ} \mathrm{C}\right)$ by refluxing for $6 \mathrm{~h}$ in a Soxhlet extractor. The extracted lipids were concentrated in a rotary evaporator by distillation at reduced pressure and $45 \pm 5^{\circ} \mathrm{C}$ until the solvent was totally removed. The oil extract was then dried in an oven at $100 \pm 5^{\circ} \mathrm{C}$ for $1 \mathrm{~h}$, cooled in a desiccator and weighed. The total lipid content was calculated as the mass of oil extracted per $100 \mathrm{~g}$ of sample (FIRESTONE, 2014; HORWITZ et al., 2012; ZENEBON; PASCUET, 2005).

\subsubsection{Protein content}

The protein content was determined using the Kjeldahl method (ZENEBON; PASCUET, 2005), multiplying the total nitrogen content by a specific product factor $(N=6.25)$, which is a reference for vegetable products.

\subsection{Inorganic elements}

The samples were prepared in triplicate by acid digestion carried out using $0.25 \pm 0.02 \mathrm{~g}$ sample, $8 \mathrm{~mL}$ of $\mathrm{HNO}_{3}$ and $2 \mathrm{~mL}$ of $\mathrm{H}_{2} \mathrm{O}_{2}$ in a closed system assisted by microwaves (Start D, Milestone, Sorisole, Italy). The digestion was carried out at $170{ }^{\circ} \mathrm{C}$ for 37 min with $1100 \mathrm{~W}$. The extract was analysed by ICP-MS 7700x using MassHunter software (Agilent Technologies, Tokyo, Japan). The parameters used were: radiofrequency power $1550 \mathrm{~W}$; argon flow: $15 \mathrm{~L} \mathrm{~min}^{-1}$; auxiliary argon flow rate: $0.9 \mathrm{~L} \mathrm{~min}^{-1}$; flow of nebulizing gas: 1.07 L min $\mathrm{m}^{-1}$. The collision cell and octopolar reaction was used in three different modes: no gas mode; using helium

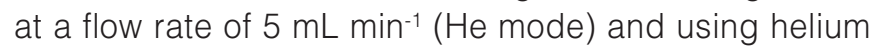
at a flow rate of $10 \mathrm{~mL} \mathrm{~min}^{-1}$ (HEHe mode). Each sample

Table 1. Weather data (temperature, relative humidity and rain) for Campo Novo do Parecis, Mato Grosso province, from February to June of 2015 , during the sunflower growing season.

\begin{tabular}{cccccc} 
Month & \multicolumn{3}{c}{ Temperature $\left({ }^{\circ} \mathbf{C}\right)$} & Relative Humidity & Rainfall \\
\cline { 2 - 3 } & Mean & Min & Max & 87.71 & 213.0 \\
February & 23.64 & 19.97 & 30.30 & 88.46 & 314.8 \\
March & 24.02 & 20.28 & 31.03 & 89.94 & 188.8 \\
April & 23.87 & 20.21 & 31.01 & 87.85 & 3.32 \\
May & 23.26 & 19.32 & 29.92 & 77.76 & 0.21 \\
June & 22.32 & 15.89 & 30.72 & & \\
\hline
\end{tabular}


was measured four times and the integration time was from 0.3 to $1.0 \mathrm{~s}$. The isotopes studied were: ${ }^{24} \mathrm{Mg},{ }^{34} \mathrm{~S},{ }^{39} \mathrm{~K},{ }^{52} \mathrm{Cr}$, ${ }^{56} \mathrm{Fe},{ }^{59} \mathrm{Co},{ }^{63} \mathrm{Cu},{ }^{95} \mathrm{Mo}$ (He mode); ${ }^{55} \mathrm{Mn},{ }^{60} \mathrm{Ni},{ }^{66} \mathrm{Zn}$ (no gas mode); and ${ }^{78} \mathrm{Se}$ (HEHe mode). The internal standards used were: ${ }^{45} \mathrm{Sc},{ }^{72} \mathrm{Ge},{ }^{89} \mathrm{Y}$ and ${ }^{103} \mathrm{Rh}$. The precision and accuracy of the method were evaluated by relative standard deviation and by recovery tests with known concentrations, respectively, and also by the use of certified reference material (RM 8433, Corn Bran, NIST, USA). The limit of detection (LOD) was calculated by 7 analytical replicates of the blank ( $8 \mathrm{~mL}$ of $\mathrm{HNO}_{3}$ and $2 \mathrm{~mL}$ of $\mathrm{H}_{2} \mathrm{O}_{2}$ ) with the lowest analytical concentration (HORWITZ et al., 2012).

\subsection{Statistical analyses}

For the statistical analysis of the inorganic elements, one-way ANOVA and Tukey were used with the XLSTAT software (Addinsoft, Paris, France), and for the analysis by hierarchical clustering (HCA), Pirouette software (Infometrix, Woodinville, USA) was used.

The other parameters were submitted to the one-way ANOVA and Scott-Knott test using the SISVAR software (FERREIRA, 2011).

\section{Results and discussion}

\subsection{Crop characterization}

The hybrids BRS G44 and G46 showed early initial flowering (Table 2), and for this reason, they spent less time in the field, being less subject to minor pest attacks when compared to the others, resulting in only minor losses in the production and quality of the achenes. The remaining hybrids could be considered as early-cycle plants, since, according to Rossi (1998), early-cycle

Table 2. Mean values for days for initial flowering (DIF), harvest index $(\mathrm{HI})$, mass of thousand achenes (MTA) and productivity in achenes (PRO) for hybrids grown in the test field located in the Midwest region of Brazil.

\begin{tabular}{ccccc}
\hline Hybrids & DIF & HI & MTA (g) & PRO (kg ha-1) \\
\hline BRS G43 & $55.00^{d}$ & $0.58^{\mathrm{b}}$ & $47.48^{\mathrm{c}}$ & $1486.21^{\mathrm{b}}$ \\
BRS G44 & $51.25^{\mathrm{e}}$ & $0.64^{\mathrm{a}}$ & $56.64^{\mathrm{b}}$ & $1934.89^{\mathrm{a}}$ \\
BRS G45 & $59.00^{\mathrm{b}}$ & $0.52^{\mathrm{c}}$ & $38.49^{\mathrm{d}}$ & $1200.70^{\mathrm{b}}$ \\
BRS G46 & $50.50^{\mathrm{e}}$ & $0.62^{\mathrm{a}}$ & $37.84^{\mathrm{d}}$ & $1435.15^{\mathrm{b}}$ \\
HLA 2013 & $57.00^{\mathrm{c}}$ & $0.58^{\mathrm{b}}$ & $33.62^{\mathrm{d}}$ & $1214.16^{\mathrm{b}}$ \\
HLA 2014 & $57.50^{\mathrm{c}}$ & $0.50^{\mathrm{c}}$ & $40.92^{\mathrm{d}}$ & $1378.72^{\mathrm{b}}$ \\
HLA 2015 & $59.50^{\mathrm{b}}$ & $0.52^{\mathrm{c}}$ & $36.22^{\mathrm{d}}$ & $1216.46^{\mathrm{b}}$ \\
HLA 2016 & $54.75^{\mathrm{d}}$ & $0.57^{\mathrm{b}}$ & $37.84^{\mathrm{d}}$ & $1424.78^{\mathrm{b}}$ \\
HLA 2017 & $57.50^{\mathrm{c}}$ & $0.61^{\mathrm{a}}$ & $35.83^{\mathrm{d}}$ & $1262.66^{\mathrm{b}}$ \\
M 734 & $56.00^{\mathrm{c}}$ & $0.62^{\mathrm{a}}$ & $50.56^{\mathrm{c}}$ & $1669.35^{\mathrm{a}}$ \\
NTC 90 & $59.00^{\mathrm{b}}$ & $0.65^{\mathrm{a}}$ & $74.09^{\mathrm{a}}$ & $1256.34^{\mathrm{b}}$ \\
SYN 045 & $56.25^{\mathrm{c}}$ & $0.65^{\mathrm{a}}$ & $47.48^{\mathrm{c}}$ & $1773.79^{\mathrm{a}}$ \\
SYN 065 & $62.75^{\mathrm{a}}$ & $0.39^{\mathrm{d}}$ & $29.10^{\mathrm{d}}$ & $808.10^{\mathrm{c}}$ \\
\hline
\end{tabular}

Different letters for the same parameter indicate significant differences $(p<0.01)$. plants are those presenting an emergence period up to flowering of from 55 to 65 days. Poletine et al. (2013), in an experiment carried out in Umuarama - PR evaluated the genetic parameters of 23 sunflower hybrids under conditions of Caiuá Sandstone and found similar values for the DIF of some cultivars. Similar results were observed by Nobre et al. (2012), indicating that there is a pattern of development, regardless of place of farming, as already mentioned by Zobiole et al. (2010). In other words, initial flowering may not be related to the climatic regularity, but to the difference in genotypes (NOBRE et al., 2012).

In terms of harvest index $(\mathrm{HI})$, the value closest to 1 is desired, namely the mass of achenes corresponding to the head with the largest possible mass. The highest values for this index were observed for the hybrids NTC 90, BRS G44, SYN 045, M 734, BRS G46 and HLA 2017 (Table 2), with values between 0.61 and 0.65 and no statistical differences between them. On the other hand, SYN 065 presented the head with the lowest mass and a value for $\mathrm{HI}$ of about 0.39. Gul and Kara (2015) also observed significant differences in this parameter between hybrids grown in the same field, assigning this behaviour to the genetics of the cultivars.

For the mass of a thousand achenes (MTA), the hybrids that showed the highest values were NTC 90 (74.09 g) and BRS G44 (56.64 g), which were statistically different from each other (Table 2). The first one is a confectionary hybrid, which explains the achene size. Of the hybrids analysed, M734 presented a value of $50.56 \mathrm{~g}$ and is the one most studied by other authors, with a great variation between the results. This value is lower than that found in the study of Pivetta et al. (2012), who reported a value of $62.80 \mathrm{~g}$ for this hybrid. Balbinot Junior et al. (2009), using the same hybrid in an experiment carried out in the South of Brazil in 2007, obtained a mean of $64.50 \mathrm{~g}$. Moreover, Amorin et al. (2007) evaluated 15 sunflower genotypes in Campinas and found that the hybrid M 734 showed the best results, noting that the MTA was $43.00 \mathrm{~g}$.

The productivity in terms of achenes (PRO) was higher for BRS G44, M 734 and SYN 045, with values of $1934.89,1669.35$ and $1773.79 \mathrm{~kg} \mathrm{ha}^{-1}$, respectively (Table 2). These values are in agreement with those reported by Conab (2015) for the national average yield for the 2014/15 sunflower harvest. On the other hand, SYN 065 was the least productive (808.10 kg ha-1). Nobre et al. (2012) carried out experiments in two locations in the Southeast region of Brazil in the agricultural year of 2011. Of the hybrids tested, M 734 showed important variation according to location, with results considered as low productivity (761.6 $\mathrm{kg} \mathrm{ha}^{-1}$ ) compared to the value obtained in the present work, to high values (2299.11 kg ha-1), such that one can assert that each hybrid is expressed differently in each region. This finding was also emphasized by Rodrigues et al. (2011), who evaluated the behaviour of 
sunflower genotypes in different regions in the Northeast of Brazil, and observed that when testing a hybrid in different regions, the productivity tended to fluctuate greatly from one location to another, thus justifying the yield found, which varied from $1602 \mathrm{~kg} \mathrm{ha}^{-1}$ to $2272 \mathrm{~kg} \mathrm{ha}^{-1}$.

\subsection{Grain characterization}

Given the current great variability in sunflower seed hybrids, it is important to know the effects of genetic modifications on the characteristics of these seeds and on their suitability for different purposes (GUPTA, 2014). Table 3 shows the chemical composition of the sunflower grains, and the values were similar to those reported in the literature (MOURAD et al., 2016; FREITAS; LAGO, 2007; ROCHE et al., 2004). The mean oil content was $33.31 \%$ to $42.79 \%$, except for NTC 90 which showed up to $50 \%$ less than the other samples (BRS G46 and HLA 2014). Overall, the values found for the mean oil content were similar to those found by Zheljazkov et al. (2011), who evaluated the effect of hybrid and planting date on the yield, oil content and oil composition of sunflower in five locations in Mississippi, and the main oil content was 38\% to $42.6 \%$. Howell et al. (2015) also found similar values for the sunflower oil content during a study carried out during the 2009 and 2011 seasons in the Southern High Plains of the USA.

According to Gupta (2014) non-oil type seeds and seeds for animal nutrition are relatively thick and large, with striped hulls that are only loosely attached to the kernels. These characteristics, besides the low oil content, were observed for the sample NTC 90 (data not shown) such that this hybrid can be classified as a confectionary seed. The large size remains intact and goes into the in-shell market to be consumed as a snack in countries like Egypt, Syria, Israel, Turkey, Malaysia and the Mediterranean (GUPTA, 2014).
The oil content is a characteristic of particular relevance for oleaginous seeds such as sunflower, since in some countries, like the United States, the producers may be paid rewards for seeds containing more than $40 \%$ oil (ZHELJAZKOV et al., 2011; NSA, 2009). Radić et al. (2009) stated that environmental factors and locality affect sunflower seed germination and the oil content, making the oil content a quantitative attribute conditioned by both genetic and environmental factors.

Since sunflower oil cake is a by-product of the oil industry and an alternative and economic source of proteins, due their good nutritional quality (SALGADO et al., 2012), knowledge of the protein content of each cultivar is the basis of decisions taken to develop foods with desired characteristics. In the present study the protein content varied from $14.88 \%$ for SYN 045 to $21.07 \%$ for BRS G46 (Table 3). It was also observed that although the hybrid SYN 45 showed an above average oil content it had a low protein content. On the subject of correlation between lipids and proteins, research has shown conflicting results. On one hand, there are results that attest to an inverse relationship between these components (BRIGANTE, 2013; El ASRI et al., 2000; ROCHE et al., 2004; TAVOLJANSKIY et al., 2004; PIVA et al., 2000). Conversely, Radić et al. (2009) observed no negative relationship between the protein and lipid contents.

Regarding the ash content, the values were slightly higher than those found by Mourad et al. (2016) for hybrid Brazilian seeds.

\subsection{Inorganic elements}

With respect to the mineral content, all the hybrids analysed showed significant differences (Table 4). Overall, the samples had higher concentrations of $\mathrm{K}, \mathrm{Mg}, \mathrm{S}, \mathrm{Fe}$, $\mathrm{Zn}, \mathrm{Mn}, \mathrm{Cr}, \mathrm{Ni}$ and $\mathrm{Cu}$ while the Mo, Co and Se contents were lower. There are few reports about the mineral

Table 3. Chemical composition of the sunflower grains*

\begin{tabular}{|c|c|c|c|c|}
\hline Sample & Lipid (\%) & Protein (\%) & Ash (\%) & Carbohydrate $(\%)^{* *}$ \\
\hline BRS G43 & $34.31 \pm 0.13^{c}$ & $17.55 \pm 0.15^{d}$ & $4.15 \pm 0.04^{e}$ & $43.99 \pm 0.25^{c}$ \\
\hline BRS G44 & $37.49 \pm 0.21^{d}$ & $15.10 \pm 0.11^{a}$ & $4.11 \pm 0.05^{e}$ & $43.28 \pm 0.26^{c}$ \\
\hline BRS G45 & $34.82 \pm 0.03^{c}$ & $20.33 \pm 0.10^{f}$ & $4.58 \pm 0.01^{h}$ & $40.26 \pm 0.07^{b}$ \\
\hline BRS G46 & $40.39 \pm 0.30^{f}$ & $21.07 \pm 0.10^{g}$ & $4.31 \pm 0.03^{f}$ & $34.19 \pm 0.45^{a}$ \\
\hline HLA 2013 & $33.31 \pm 0.26^{b}$ & $17.24 \pm 0.23^{d}$ & $4.46 \pm 0.03^{g}$ & $44.99 \pm 0.34^{d}$ \\
\hline HLA 2014 & $42.79 \pm 0.07 \mathrm{~g}$ & $17.42 \pm 0.21 \mathrm{~d}$ & $4.01 \pm 0.03^{d}$ & $35.79 \pm 0.20$ a \\
\hline HLA 2015 & $40.00 \pm 0.02^{f}$ & $16.06 \pm 0.20^{b}$ & $3.93 \pm 0.07^{c}$ & $40.00 \pm 0.13^{b}$ \\
\hline HLA 2016 & $39.18 \pm 0.04^{e}$ & $16.04 \pm 0.27 b$ & $3.94 \pm 0.03^{c}$ & $40.84 \pm 0.34 b$ \\
\hline HLA 2017 & $37.12 \pm 0.06^{d}$ & $17.82 \pm 0.21^{e}$ & $4.28 \pm 0.06^{f}$ & $40.79 \pm 0.15^{b}$ \\
\hline M734 & $36.45 \pm 1.58^{c}$ & $16.87 \pm 0.01^{c}$ & $3.62 \pm 0.01^{b}$ & $44.05 \pm 0.17^{d}$ \\
\hline NTC 90 & $20.26 \pm 0.26^{a}$ & $16.57 \pm 0.09 c$ & $4.04 \pm 0.02^{d}$ & $59.14 \pm 0.20^{e}$ \\
\hline SYN 045 & $37.21 \pm 0.08^{d}$ & $14.88 \pm 0.29 a$ & $3.48 \pm 0.011^{a}$ & $44.42 \pm 0.38^{c}$ \\
\hline SYN 065 & $38.81 \pm 0.22^{e}$ & $16.55 \pm 0.24^{c}$ & $4.02 \pm 0.08^{d}$ & $40.62 \pm 0.41^{b}$ \\
\hline
\end{tabular}

${ }^{*}$ The mean values are given on a dry weight basis \pm standard deviation $(n=3)$; ${ }^{* *}$ by difference; Different letters for the same parameter indicate significant differences $(p<0.05)$. 


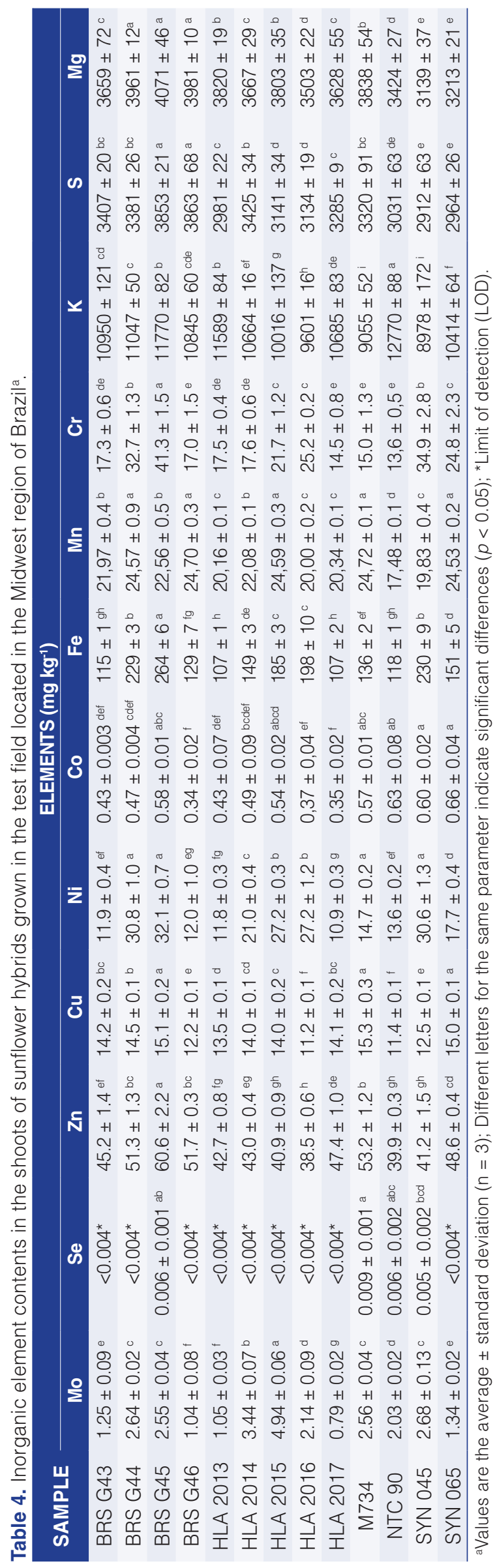


composition of sunflower seeds. Özcan (2006) found the following values for sunflower kernels from Turkey: $\mathrm{Mg}\left(2251 \mathrm{mg} \mathrm{kg}^{-1}\right) ; \mathrm{K}\left(8754 \mathrm{mg} \mathrm{kg}^{-1}\right) ; \mathrm{Cr}\left(2.2 \mathrm{mg} \mathrm{kg}^{-1}\right)$; $\mathrm{Mn}\left(7.0 \mathrm{mg} \mathrm{kg}^{-1}\right)$; Fe $\left(49.7 \mathrm{mg} \mathrm{kg}^{-1}\right)$; Ni $\left(5.7 \mathrm{mg} \mathrm{kg}^{-1}\right)$; $\mathrm{Cu}\left(18.1 \mathrm{mg} \mathrm{kg}^{-1}\right)$ and $\mathrm{Zn}\left(36.5 \mathrm{mg} \mathrm{kg}^{-1}\right)$, values which are lower than those found in the present work, except for $\mathrm{Cu}$. With respect to Brazilian seeds, Chaves et al. (2010) analysed those from the Southern region and obtained average values of: $\mathrm{Mg}\left(3500 \mathrm{mg} \mathrm{kg}^{-1}\right) ; \mathrm{K}\left(7100 \mathrm{mg} \mathrm{kg}^{-1}\right)$; $\mathrm{Mn}\left(24.3 \mathrm{mg} \mathrm{kg}^{-1}\right)$; Fe (62.1 $\left.\mathrm{mg} \mathrm{kg}^{-1}\right)$; Co $\left(0.31 \mathrm{mg} \mathrm{kg}^{-1}\right)$; $\mathrm{Ni}\left(1.0 \mathrm{mg} \mathrm{kg}^{-1}\right)$; $\mathrm{Cu}\left(17.1 \mathrm{mg} \mathrm{kg}^{-1}\right) ; \mathrm{Zn}\left(46.5 \mathrm{mg} \mathrm{kg}^{-1}\right)$ and Mo $\left(0.11 \mathrm{mg} \mathrm{kg}^{-1}\right)$. Despite the fact that these concentrations were obtained from unpeeled seeds, the samples showed lower mineral concentrations when compared to those found in the present study, with the exception of $\mathrm{Mn}, \mathrm{Cu}$ and $\mathrm{Zn}$. To demonstrate the influence of de-hulling on the mineral content, Wang et al. (2009) investigated lentils (Lens culinaris) from Canada, and observed a significant difference between raw and hulled lentils. There was a decrease in the $\mathrm{Ca}, \mathrm{Cu}, \mathrm{Fe}, \mathrm{Mg}$ and $\mathrm{Mn}$ contents of the hulled lentils and an increase in the $\mathrm{K}$ and $\mathrm{P}$ contents.
Each hybrid analysed showed random characteristics amongst the elements assessed. BRS G45 showed the presence of higher concentrations of the following elements: $\mathrm{Mg}, \mathrm{S}, \mathrm{Cr}, \mathrm{Fe}, \mathrm{Ni}, \mathrm{Cu}$ and $\mathrm{Zn}$, followed by BRS G44 with higher contents of $\mathrm{Mg}, \mathrm{Cr}, \mathrm{Mn}, \mathrm{Fe}$ and $\mathrm{Ni}$. The other hybrids showed the following behaviour with respect to higher levels of elements: BRS G46: Mg, S and Mn; SYN 045: Cr, Fe and Co; SYN 065: Mn, Co and Cu; M734: Mn, Cu and Se; NTC 90: K and Co; HLA 2015: Mn and Mo and HLA 2014: Mo.

The analysis of variance and Tukey's test allowed one to verify there were major variations in $\mathrm{K}, \mathrm{Fe}, \mathrm{Zn}, \mathrm{Co}$, $\mathrm{Ni}, \mathrm{Cu}$ and Mo amongst the hybrids, which was confirmed by HCA, making it feasible to classify them according to their mineral compositions, especially in relation to $\mathrm{K}, \mathrm{Co}$, $\mathrm{Mn}$ and $\mathrm{Cu}$. Jumbe et al. (2016) stated the importance of consuming seeds with high mineral contents and suggested that the incorporation of sunflower oil into cooking methods might increase the mineral dietary uptake.

Five distinct groups could be observed on the HCA dendogram (Figure 1; 0.55 similarity degree), while three groups can be highlighted: Morgan M734, NTC 90 and

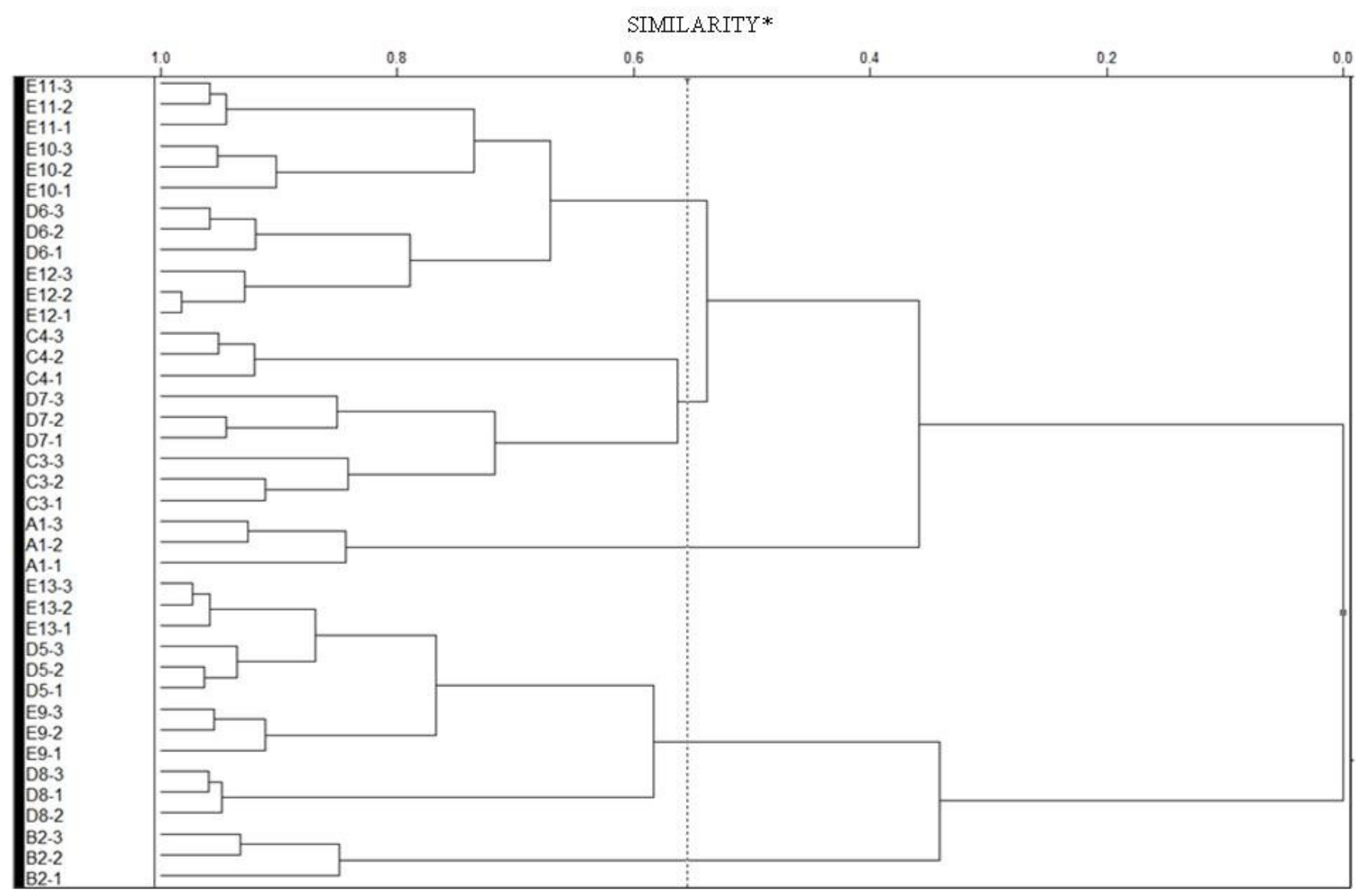

Figure 1. Dendrogram of the similarity indices for sunflower hybrids grown in the test field located in the Midwest region of Brazil. ${ }^{*} \mathrm{~A} 1=\mathrm{M} 734, \mathrm{~B} 2=\mathrm{NTC} 090, \mathrm{C} 3=\mathrm{SYN} 045, \mathrm{C} 4=$ SYN 065, D5 = BRS G43, D6 = BRS G44, D7 = BRS G45, D8 = BRS G46, $\mathrm{E9}=\mathrm{HLA}$ 2013, E10 = HLA 2014, E11 = HLA 2015, E12 = HLA 2016, E13 = HLA 2017. 
Essential elements, oil and protein contents of sunflower hybrids grown in Brazil

Amaral, R. D. A. et al.

the SYN group (SYN 045 and SYN 065), according to the predominance of $\mathrm{Mn}, \mathrm{Cu}$ and Se; K; and Co, respectively. It was also observed, with a higher degree of similarity (>0.8), that the analytical replicates could be grouped due to the high similarity between them. This feature demonstrated the homogeneity of the samples and the accuracy of the method used to quantify the elements.

\section{Conclusions}

The results presented here show that is possible to obtain hybrids which combine the main goal of oil production with characteristics that make them apt for alternative uses of their by-products, this being a great opportunity to increase the farm income. The hybrid BRS G46 is a good example of this dual purpose, and can be used to obtain products with higher nutritional quality and protein value.

Overall, the results obtained showed that BRS G45 contained, on average, higher concentrations of the following elements: $\mathrm{Mg}>\mathrm{S}>\mathrm{Fe}>\mathrm{Zn}>\mathrm{Cr}>\mathrm{Ni}>\mathrm{Cu}$, followed by BRS G44, which showed higher contents of $\mathrm{Mg}>\mathrm{Fe}>\mathrm{Cr}>\mathrm{Ni}>\mathrm{Mn}$, besides presenting the highest productivity of achenes.

The integrated study of the parameters of achene productivity and the oil protein and essential element contents in new sunflower hybrids allowed for their selection for specific purposes both in the field and post-harvest.

\section{Acknowledgements}

The present work was supported by the Ministério da Ciência, Tecnologia e Inovação/ Conselho Nacional de Desenvolvimento Científico e Tecnológico - 402022/2014-9.

\section{References}

ALBERIO, C.; IZQUIERDO, N. G.; AGUIRREZÁBAL, L. A. N. Sunflower crop physiology and agronomy. In: FORCE, E. M.; DUNFORD, N. T.; SALAS, J. J. Sunflower chemistry, production, processing and utilization. Illinois: AOCS US, 2016. Chap. 3, p. 53-91.

AMORIN, P. E.; RAMOS, P. N.; UNGARO, G. R. M.; KIIHL, M. A. T. Divergência genética em genótipos de girassol. Ciência e Agrotecnologia, v. 31, n. 6, p. 1637-1644, 2007.

BALBINOT JUNIOR, A. A.; BACKES, R. L.; SOUZA, A. M. Desempenho de cultivares de girassol em três épocas de semeadura no planalto norte catarinense. Scientia Agraria, v. 10, n. 2, p. 127-133, 2009

BRIGANTE, G. P. Deterioração de sementes de girassol durante o armazenamento. 2013. 206f. Tese (Doutorado em Agronomia/Fitotecnia - Produção Vegetal)--Universidade Federal de Lavras, Lavras, 2013

CASTRO, C.; FARIAS, J. R. B. Ecofisiologia do girassol. In: LEITE, R. M. V. B. C.; BRIGHENTI, A. M.; CASTRO, C. (Ed.).
Girassol no Brasil. Londrina: Empresa Brasileira de Pesquisa Agropecuária - CNPSo, 2005. p. 163-210.

CHAVES, E. S.; DOS SANTOS, E. J.; ARAUJO, R. G. O.; OLIVEIRA, J. V.; FRESCURA, V. L. A.; CURTIUS, A. J. Metals and phosphorus determination in vegetable seeds used in the production of biodiesel by ICP-OES and ICP-MS. Microchemical Journal, v. 96, n. 1, p. 71-76, 2010. http://dx.doi.org/10.1016/j. microc.2010.01.021.

COMPANHIA NACIONAL DE ABASTECIMENTO - CONAB. Conjuntura mensal: girassol período março de 2017. Brasília, 2015. Available at: <http://www.conab.gov.br/OlalaCMS/uploads/ arquivos/17_04_10_10_06_42_girassol_-_conjuntura_mensal_-marco_de_2017.pdf>. Accessed on: 28 nov. 2017

CORREIA, P. R. M.; FERREIRA, M. M. C. Reconhecimento de padrões por métodos não supervisionados: explorando procedimentos quimiométricos para tratamento de dados analíticos. Química Nova, v. 30, n. 2, p. 481-487, 2007.

DALCHIAVON, F. C.; CARVALHO, M. P.; FREDDI, O. S.; ANDREOTTI, M.; MONTANARI, R. Variabilidade espacial da produtividade do feijoeiro correlacionada com atributos químicos de um Latossolo Vermelho Distroférrico sob sistema de semeadura direta. Bragantia, v. 70, n. 4, p. 908-916, 2011.

DALCHIAVON, F. C.; MONTANARI, R.; ANDREOTTI, M.; DALLACORT, R.; SOUZA, M. F. P. Relationship between sunflower productivity and soil's chemical properties by geo-statistical techniques. African Journal of Agricultural Research, v. 10, n. 35, p. 3525-3532, 2015. http://dx.doi.org/10.5897/AJAR2014.9472.

DE LA VEGA, A. J.; DELACY, I. H.; CHAPMAN, S. C. Progress over 20 years of sunflower breeding in central Argentina. Field Crops Research, v. 100, n. 1, p. 61-72, 2007. http://dx.doi. org/10.1016/j.fcr.2006.05.012.

EL ASRI, M.; ESSAHAT, A.; BOUNIOLS, A.; MONDIÈS, M. Rendement et qualité des graines du tournesol cultivé sous contraintes hydriques: résultats des essais en coopération au Maroc et dans le Sud-Ouest de la France. In: INTERNATIONAL SUNFLOWER CONFERENCE, 15., 2000, Toulouse. Proceedings... Toulouse: ISA, 2000. p. 127-132.

FERREIRA, D. F. Sisvar: a computer statistical analysis system. Ciência e Agrotecnologia, v. 35, n. 6, p. 1039-1042, 2011.

FIRESTONE, D. Official methods and recommended practices of the American Oil Chemists Society. 3rd ed. Illinois: AOCS, 2014.

FORCE, E. M.; DUNFORD, N. T.; SALAS, J. J. Sunflower chemistry, production, processing and utilization. Illinois: AOCS, 2015.

FREITAS, S. P.; LAGO, R. C. A. Equilibrium data for the extraction of coffee and sunflower oils with ethanol. Brazilian Journal of Food Technology, v. 10, n. 3, p. 220-224, 2007. 
Essential elements, oil and protein contents of sunflower hybrids grown in Brazil

Amaral, R. D. A. et al.

GUL, V.; KARA, K. Effects of different nitrogen doses on yield and quality traits of common sunflower (Helianthus annuus L.). Turkish Journal of Food Crops, v. 20, n. 2, p. 159-165, 2015.

GUPTA, M. K. Sunflower oil: history, applications and trends. Lipid Technology, v. 26, n. 12, p. 260-263, 2014.

HORWITZ, W.; LATIMER, J. R.; GEORGE, W. Official methods of analysis of the Association of Official Analytical Chemists. 19th ed. Gaithersburg: AOAC, 2012.

HOWELL, T. A.; EVETT, S. R.; TOLK, J. A.; COPELAND, K. S.; MAREK, T. H. Evapotranspiration, water productivity and crop coefficients for irrigated sunflower in the U.S. southern high plains. Agricultural Water Management, v. 162, p. 33-46, 2015. http://dx.doi.org/10.1016/j.agwat.2015.08.008.

ION, V.; DICU, G.; BASA, A. G.; DUMBRAVA, M.; TEMOCICO, G.; EPURE, L. I.; STATE, D. Sunflower yield and yield components under different sowing conditions. Agriculture and Agricultural Science Procedia, v. 6, p. 44-51, 2015. http://dx.doi.org/10.1016/j. aaspro.2015.08.036.

IZQUIERDO, N.; AGUIRREZÁBAL, L.; ANDRADE, F.; PEREYRA, $V$. Night temperature affects fatty acid composition in sunflower oil depending on the hybrid and the phenological stage. Field Crops Research, v. 77, n. 2-3, p. 115-126, 2002. http://dx.doi. org/10.1016/S0378-4290(02)00060-6.

JUMBE, T. J.; PICKENS, C. A.; VALENTINI, K.; ADJEPONG, M.; LI, W.; KINABO, J. L.; FENTON, J. I. Evaluation of fatty acid and mineral content of Tanzanian seeds and oils. Journal of Food Composition and Analysis, v. 50, p. 108-113, 2016. http:// dx.doi.org/10.1016/j.jfca.2016.05.016.

KIRBASLAR, F. G.; TÜRKER, G.; ÖZSOY-GÜNES, Z.; ÜNAL, M.; DÜLGER, B.; ERTAS, E.; KIZILKAYA, B. Evaluation of fatty acid composition, antioxidant and antimicrobial activity, mineral composition and calorie values of some nuts and seeds from Turkey. Records of Natural Products, v. 6, n. 4, p. 339-349, 2012.

KÖTSCHAU, A.; BÜCHEL, G.; EINAX, J. W.; MIRGORODSKY, D.; MEISSNER, R.; VON TÜMPLING, W.; MERTEN, D. Element contents in shoots of sunflower (Helianthus annuus): prediction versus measuring. Chemie der Erde, v. 74, n. 3, p. 385-391, 2014. http://dx.doi.org/10.1016/j.chemer.2014.02.006.

MOURAD, A. L.; REGITANO NETO, A.; MIGUEL, A. M. R. O.; HENRIQUES, E. A.; ALVES, R. M. V. Storage stability of three genotypes of sunflower seeds. Industrial Crops and Products, V. 80, p. 6-16, 2016. http://dx.doi.org/10.1016/j.indcrop.2015.10.044.

NATIONAL SUNFLOWER ASSOCIATION - NSA. Sunflower oil. Mandan, 2009. Available at: <http://www.sunflowernsa.com>. Accessed on: 13 may 2016.

NOBRE, C. A. D.; REZENDE, F. C. J.; BRANDÃO JUNIOR, D. S. D.; COSTA, A. C.; MORAIS, B. L. D. Desempenho agronômico de genótipos de girassol no norte de Minas Gerais. Revista Agro@mbiente On-line, v. 6, n. 2, p. 140-147, 2012.
ÖZCAN, M. M. Determination of the mineral compositions of some selected oil-bearing seeds and kernels using Inductively Coupled Plasma Atomic Emission Spectrometry (ICP-AES). Grasas y Aceites, v. 57, n. 2, p. 211-218, 2006.

PIVA, G.; BOUNIOLS, A.; MONDIÈS, M. Effect of cultural conditions on yield, oil content and fatty acid composition of sunflower kernel. INTERNATIONAL SUNFLOWER CONFERENCE, 15. 2000, Toulouse. Proceedings... Toulouse: ISA, 2000, p. A61-A66.

PIVETTA, L. G.; GUIMARÃES, V. F.; FIOREZE, S. L.; PIVETTA, L. A.; CASTOLDI, G. Avaliação de híbridos de girassol e relação entre parâmetros produtivos e qualitativos. Revista Ciência Agronômica, v. 43, n. 3, p. 561-568, 2012.

POLETINE, P. J.; SAPIA, G. J.; MACIEL, G. D. C. Parâmetros genéticos em híbridos de girassol nas condições de Arenito Caiuá. Journal of Agronomic Sciences, v. 2, n. 2, p. 132-147, 2013.

RADIĆ, V.; VUJAKOVIĆ, M.; MARJANOVIĆ-JEROMELA, A.; MRĐA, J.; MIKLI , V.; DUŠANIĆ, N.; BALALIĆ, I. Interdependence of sunflower seed quality parameters. Helia, v. 32, n. 50, p. 157-164, 2009. http://dx.doi.org/10.2298/HEL0950157R.

ROCHE, J.; BOUNIOLS, A.; MOULOUNGUI, Z.; BARRANCO, T.; CERNY, M. Management of environmental crop conditions to produce useful sunflower oil components. European Journal of Lipid Science and Technology, v. 108, p. 287-297, 2006.

ROCHE, J.; ESSAHAT, A.; BOUNIOLS, A.; ASRI, E.; MOULOUNGUI, Z.; MONDIĖS, M.; ALGHOUM, M. Diversified composition of sunflower (Helianthus annus L.) seeds within cultural practices and genotypes (hybrids and populations). Helia, v. 27, n. 40, p. 73-98, 2004. http://dx.doi.org/10.2298/HEL0440073R.

RODRIGUES, R. C.; CARVALHO, L. W. H.; OLIVEIRA, R. I.; CARVALHO, P. G. C.; FERREIRA, B. M. F.; TABOSA, N. J.; LIRA, A. M.; CASTRO, R. C.; MENEZES, M. M. V. Comportamento de genótipos de girassol de ensaio final de segundo ano no nordeste brasileiro. In: REUNIÃO NACIONAL DE PESQUISA DE GIRASSOL, 19., SIMPÓSIO NACIONAL SOBRE A CULTURA DO GIRASSOL, 7., 2011, Aracaju. Anais... Aracaju: EMBRAPA, 2011. p. 267-269.

ROSSI, R. O. Girassol. Curitiba: Tecnagro, 1998.

SALGADO, P. R.; ORTIZ, S. E. M.; PETRUCCELLI, A. N. M. Functional food ingredients based on sunflower protein concentrates naturally enriched with antioxidant phenolic compounds. Journal of the American Oil Chemists' Society, v. 89, n. 5, p. 825-836, 2012. http://dx.doi.org/10.1007/s11746-011-1982-x.

SOUSA, D. M. G.; LOBATO, E. Cerrado: correção do solo e adubação. 2. ed. Brasília, DF: Embrapa Informação Tecnológica, 2004.

TAVOLJANSKIY, N. P.; CHIRYAEV, P. V.; SCHERSTYUK, S. V.; ALTINNIKOVA, V. I.; TIKHOMIROV, V. T. Development of original material for sunflower breeding for seed characteristics, oil and protein quality in the conditions of central-chernozem region. 
Essential elements, oil and protein contents of sunflower hybrids grown in Brazil

Amaral, R. D. A. et al.

Helia, v. 27, n. 40, p. 117-122, 2004. http://dx.doi.org/10.2298/ HEL0440117T.

WANG, N.; HATCHER, D. W.; TOEWS, R.; GAWALKO, E. J. Influence of cooking and dehulling on nutritional composition of several varieties of lentils (Lens culinaris). LebensmittelWissenschaft + Technologie, v. 42, n. 4, p. 842-848, 2009. http://dx.doi.org/10.1016/j.Iwt.2008.10.007.

ZENEBON, O.; PASCUET, N. S. Métodos físico-químicos para análise de alimentos. 4. ed. Brasília: Ministério da Saúde/ ANVISA; São Paulo: Instituto Adolfo Lutz, 2005.
ZHELJAZKOV, V. D.; VICK, B. A.; BALDWIN, B. S.; BUEHRING, N.; COKER, C.; ASTATKIE, T.; JOHNSON, B. Oil productivity and composition of sunflower as a function of hybrid and planting date. Industrial Crops and Products, v. 33, n. 2, p. 537-543, 2011. http://dx.doi.org/10.1016/j.indcrop.2010.11.004.

ZOBIOLE, L. H. S.; CASTRO, C.; OLIVEIRA, F. A.; OLIVEIRA JUNIOR, A. Marcha de absorção de macronutrientes na cultura do girassol. Revista Brasileira de Ciência do Solo, v. 34, n. 2, p. 425-433, 2010. 